\title{
THE NAVAL CAMPAIGN IN THE WAR OF THE PACIFIC 1879-1884
}

\author{
Capt (SAN) I.C. Little \\ Communication, SADF
}

\begin{abstract}
South Africa and Chile have always had close military and diplomatic ties but comparatively little is known in South Africa about Chilean military history. Chile's naval history in particular is most interesting and as obviously in the 18th century the only practical means of travel to and around South America was by sea, her navy has played a very important historical role. This article is an attempt to highlight one particular period of Chilean naval history.
\end{abstract}

There has also always been a very delicate balance of power amongst the nations of South America and this is particularly true of the relationships between Chile, Peru, Argentina, Paraguay and Bolivia. Each of these nations has at times formed alliances with one or the other against the rest and this uneasy balance is still maintained today. It has its roots in the Napoleonic Wars between 1800 and 1815 .

Whilst Spain was battling with political and economic problems during the above period, the Spanish colonies in South America declared their independence and embarked upon the Spanish America Wars of Independence between 1810 and 1826. Revolutionary governments came to power, armies were raised and navies formed, amongst these the Chilean Navy in 1813 and the Peruvian Navy in 1825. With the coming of general independence in 1826 new struggles developed around the borders of the five former Spanish vice-royalties and their administrative areas, now independent countries. Peru, the largest and richest of these was especially tempted to flex her muscles and between 1826 and 1879 engaged in a series of conflicts with Bolivia, Ecuador, Argentina, Chile and Spain. For this last named in 1864-1866 she had built up a powerful and new navy and had by 1879 become a regional power.

Chile had played a leading role in the liberation of Peru in her war for independence by virtue of her navy and had twice been drawn into conflict thereafter. Once (as mentioned above) with Argentina against Peru and Bolivia in 1835, and then again with Peru, Ecuador and Bolivia against Spain in 1864-1866. This last war left Chile with her navy and merchant marine wiped out, but by 1879 she had rebuilt these with new tonnage from the UK and USA and had also become a regional power. Bolivia had also emerged strengthened from these struggles and with a corridor to the sea between Peru and Chile through the Atacama desert. This gave Bolivia the seaport of Antofagasta but she made no attempt to use it as such nor to fortify it or build ships to protect it. The whole border in the area was however still in dispute and Bolivia and Chile had thus come to an agreement that Chilean nitrates mined in the Atacama desert could be shipped at nominal cost through the port of Antofagasta.

In 1878 and contrary to this agreement, Bolivia increased the taxes she levied on these Chilean nitrates, thus affecting Chile economically and also bringing the border dispute to a head.

Chile started mobilising her armed forces and activating her fleet in order to settle the border dispute by force and on 14 February 1878 a Chilean naval expedition seized the undefended port of Antofagasta. A landing force of 500 men occupied the surrounding countryside and placed Chile in effective control of the Atacama. On 1 March 1879 Bolivia declared war on Chile, knowing that she had a secret treaty with Peru to come to her aid against Chile. This treaty was however known to the Chileans who also then declared war on Peru. At this stage the combined Bolivian and Peruvian armies were twice as large as Chile's and whilst Bolivia had no navy the Peruvian and Chilean navies were numerically equal. Most observers expected Chile to lose the war but there was a subtle difference in quality in the two navies which would tip the balance in Chile's favour.

Each navy had two iron-clads but the Chilean pair, the ALMIRANTE COCHRANE and BLANCO ENCALADA were larger, faster, newer and more heavily armoured than the Peruvian pair, 


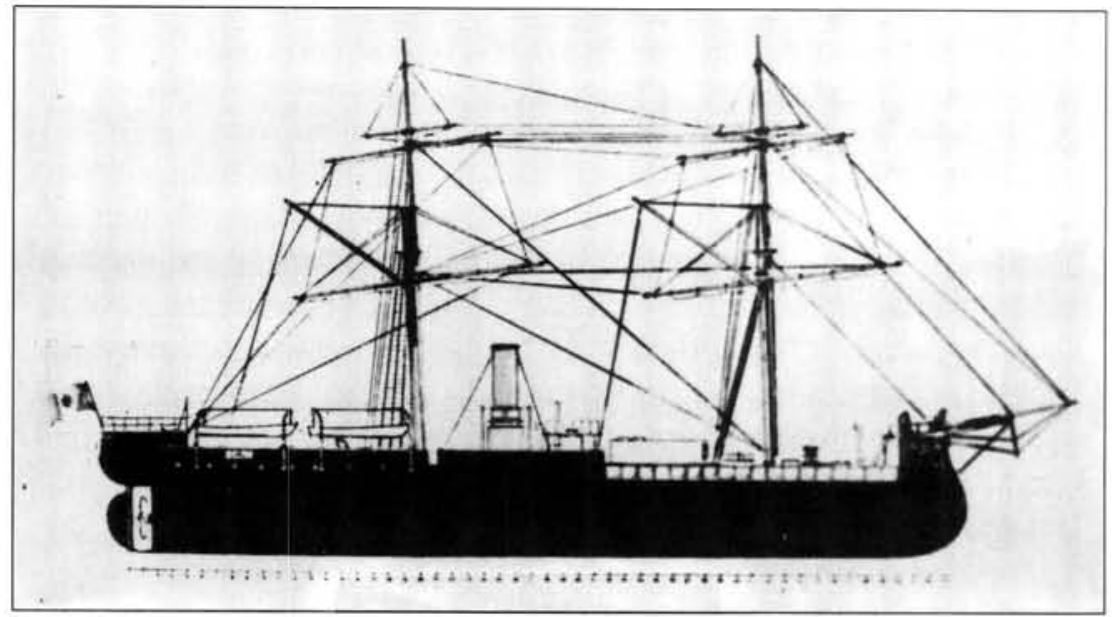

Monitor HUASCAR, 1865.

HUASCAR and INDEPENDENCIA. The Chilean Navy also had a more professional approach based on close links with the British Royal Navy, ex-members of which were serving in the Chilean Navy. The Peruvian Navy by contrast had had a run of groundings and accidents and even in one case, theft.

Their major warship, the monitor HUASCAR, had been stolen by her crew in 1876 in order to go pirating. An international alert gave rise to her being hunted down by the British ships HMS SHAH and AMETHYST. These two ships carried out the first recorded instance of a torpedo attack on the HUASCAR but it was unsuccessful. Nevertheless her pirate crew got sufficient of a fright to put back to Peru and surrender.

The HUASCAR, in 1879 still Peru's principal warship was no more than a seagoing monitor with a ram. Built during the previous war against Spain she had a main turret that was still trained by manpower. It took a team of 16 men a quarter of an hour to crank the turret to a broadside firing position and then to return it to the fore-and-aft loading position. The gun, a muzzle loader, could only be loaded by training it directly ahead and with-drawing it into the turret. It could however only be fired on the beam because the high ram forecastle blocked the

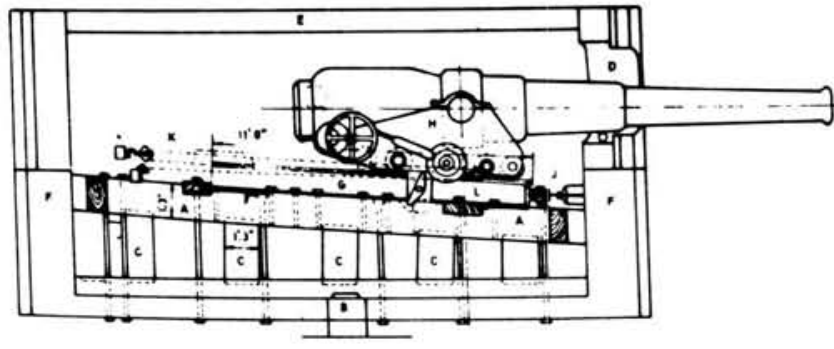

The Coles turret as fitted in HUASCAR. field of fire over the bow. It was easier to train the ship than the gun. Depending on the quality of the coal, steam pressure and the state of her boilers and bottom she made between 9 and 12,3 knots at full ahead. Her crew was made up of Peruvians, British and other assorted foreigners. Quaint as she may be to modern eyes she was for her time a formidable warship and was to play a leading role in the events which followed.

On 16 May 1879 a Peruvian convoy of three transports, the CHALACO, OROYA and LIMENA, carrying 4000 Peruvian soldiers sailed from

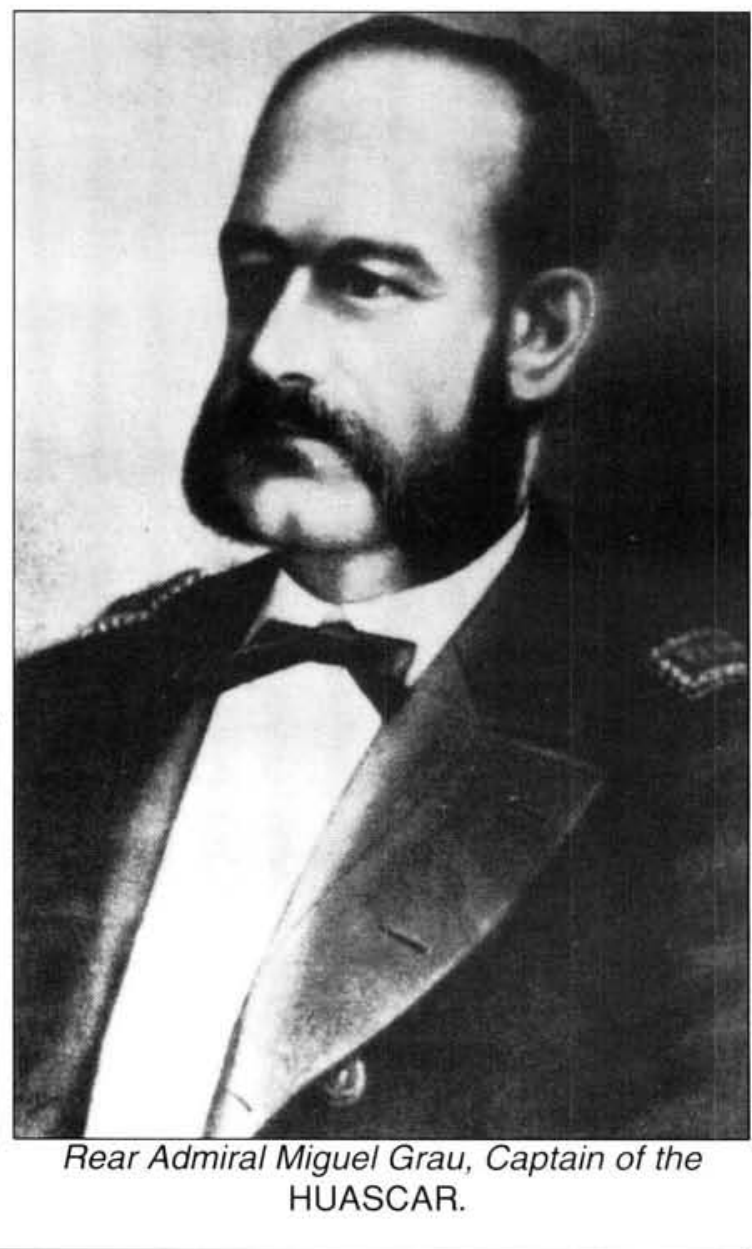


Callao. The convoy was escorted by the monitor HUASCAR and the armoured frigate INDEPENDENCIA under the command of Captains Migual Grau and J. Guillermo Moore respectively. The convoy, known as the Peruvian 1st Division and Squadron was under command of Grau and was bound for Arica. Aboard the OROYA in his capacity as President of Peru and Minister of War was Mariano Ignacio Prado accompanied by his staff. On the same day a Chilean fleet also sailed from lquique bound for Callao. On the 19th of May the two fleets actually passed each other at a distance of 31 miles apart without seeing each other.

Grau's squadron arrived in Arica and disembarked the 1st Division. Prado held a council of war and decided that the Peruvian squadron would sail immediately for lquique to sink and destroy the Chilean squadron stationed there.Iquique was still in Peruvian hands al-

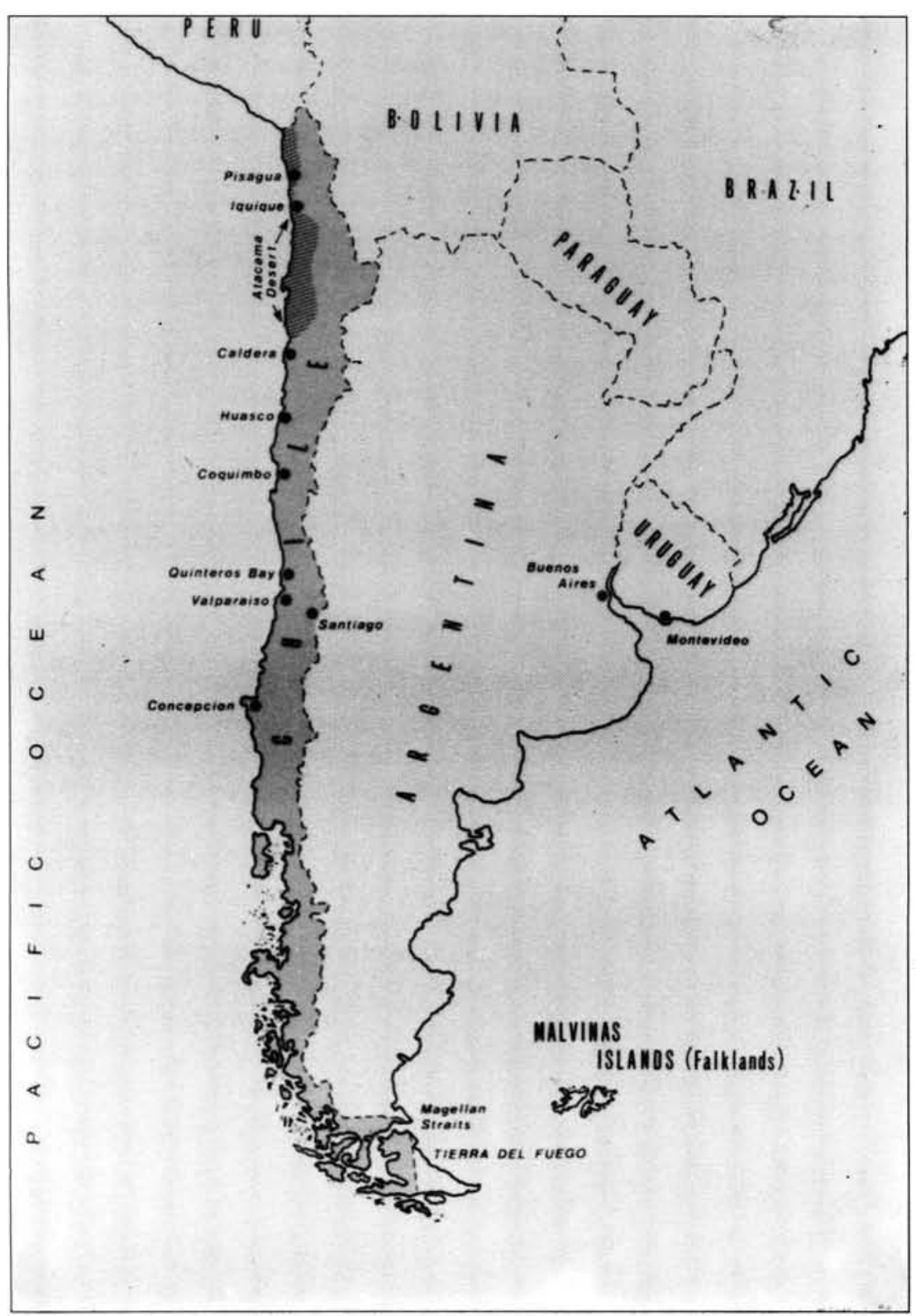

Map of operations. though Chilean ships were using the bay and blockading the port. The squadron would then sail on to Antofagasta to capture an unescorted troop convoy which had sailed North from Valparaiso on 22 May with 2500 troops to be used as reinforcements in Antofogasta.

The Peruvian plan was to descend on Antofagasta, capture this convoy, bombard the city to destroy the water condensors and military installations and render the Chilean occupying troops helpless. Thereafter the Navy would break the Chilean sea lines of communication between Antofogasta and Valparaiso forcing the Chilean garrison to surrender and placing Peru in a favourable position to win the war. The Navy was to avoid a pitched battle and concentrate on this objective. The Chileans objective was to bring the Peruvian fleet to battle, destroy it to gain mastery of the sea and then carry out a series of sea-borne invasions along the Peruvian coast.

On 16 May, as already stated, the Chilean squadron at lquique under command of Admiral Juan Williams Rebolledo prepared to sail for Callao to attack the Peruvian squadron in its home port. Acting on erroneous information obtained from the captain of the steamer LONTUE they only actually sailed in the early morning of 17 May, leaving the two weakest ships in the fleet, the frigate ESMERALDA under Cdr Arturo Prat and the figate COVADON-GA under Lt Cdr Carlos Condell to guard lquique.

Passing the opposing fleet unseen as it moved in the opposite direction Rebolledo arrived 30 miles off Callao on 21 May and prepared for a night attack. Stopping and questioning an Italian fisherman off the port, Rebolledo was horrified to find that the Peruvian fleet had sailed for the South on the same day he had sailed North. He immediately made plans to return and at 10 h00 on 22 May was on his way back 
to Iquique. Poor coal for his monitors slowed him down so he bunkered from the corvettes O'HIGGINS and CHACA-BUCO and then pushed on again. He arrived back at lquique on 30 May to find he had missed his chance for glory.

The Peruvian fleet, in accordance with the approved plan, had sailed from Arica on 20 May for Iquique via Pisagua. In the early hours of 21 May whilst Rebolledo was creeping up on Callao, Grau was approaching Iquique to carry out a reconnaissance with the intention of surprising the Chilean fleet. Unfortunately for him the COVADONGA was on patrol off the bay and at $06 \mathrm{~h} 30$ saw and recognised the Peruvian ships two miles away. She immediately fired a gun to draw her consort ESMERALDA's attention and then hoisted the flag signal "Enemy to North". Prat in the ESMERALDA signalled back" Come and Talk". followed by "prepare for action" and"have you sent the hands to breakfast? "At the same time Prat ordered the transport LAMAR at anchor in the bay to weigh anchor and escape to the South.

The ESMERALDA and COVADONGA then joined forces and Prat and Condell held a shouted council of war. Because of the immense Peruvian superiority they decided to place their ships between the Peruvians and the city but a short distance offshore so as to limit the Peruvian mobility. Prat ended up by saying to Condell "you know what you have to do?" to which Condell replied "All right". Prat then delivered a fiery speech to ESMERALDA's crew about the glory of the flag.

At $08 \mathrm{~h} 30$ a shell from the HUASCAR landed between the two Chilean ships, the crews of which promptly shouted "Viva Chile" whilst ESMERALDA replied with a furious cannonade. In the subsequent action ESMERALDA suffered a damaged boiler and with her speed reduced to three knots Prat decided to close with the HUASCAR and take her by boarding.

Laying his ship alongside HUASCAR Prat led a boarding party accompanied by a Sergeant Aldeo but before anyone else could follow, the ships drifted apart and Prat and Aldeo were shot down. ESMERALDA's first lieutenant Luis Uribe put her alongside again and Lt Serrano and 12 marines got aboard HUASCAR only to be massacred as the two ships once again parted. At the third attempt by ESMERALDA she was rammed by the HUASCAR and sank with her colours flying, taking 146 crew members with her. Only 54 of her crew of 200 survived. Lt Jorge Velarde was the HUASCAR's only casualty.
In the meantime the INDEPENDENCIA had closed with the COVADONGA which promptly headed Southwards towards the shallow coastal waters. A shell from the HUASCAR landed on the COVADONGA killing Surgeon Vidella and three crewmen but without slowing up the ship. Slipping over an offshore sandbank off Punta Gruesa the little COVADONGA scored an amazing coup when the INDEPENDENCIA in hot pursuit struck the same bank and remained hard and fast aground to become a total loss to the Peruvians. Seeing this, Grau abandoned his plan and returned to Arica, once again evading Rebolledo's fleet. With the announcement of this action morale in Chile soared and Prat and Condell became national heroes.

Grau now put the second part of the Peruvian plan into action and between May and October

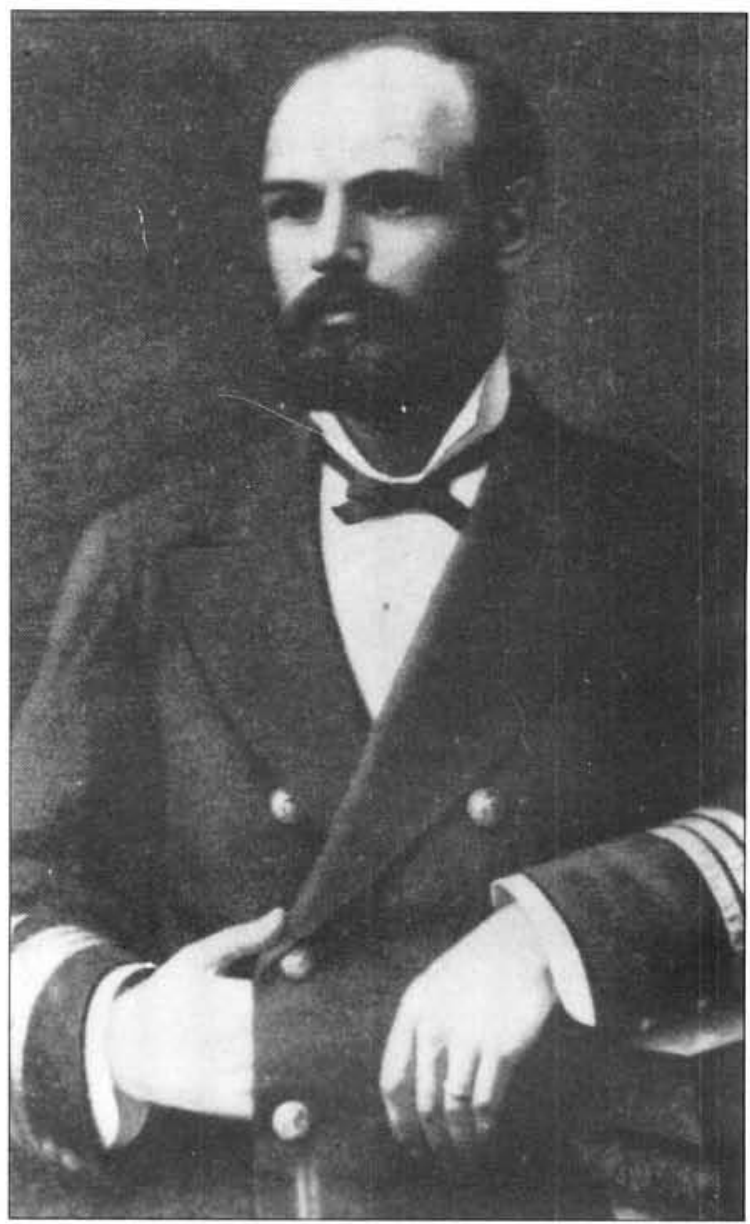

Arturo Prat. Hero of the battle of Iquique.

1879 carried out systematic commerce raiding on the Chilean lines of communication. He was continually hampered in this by poor intelligence and bad fortune. On 3 June for instance he unsuccessfully attempted to capture the Chilean naval collier MATIAS COUSINO off lquique. She escaped and alerted the Chilean monitors BLANCO ENCALADA and COCHRANE. These two ships together with the 
corvettes O'HIGGINS and CHACABUCO then tracked the HUASCAR down to the island of llo where they came upon her bunkering at anchor. By excellent seamanship and superior speed Grau managed to escape to sea and thence to Callao for repairs.

On 9 July he was back in Arica and on the night of 9/10 July 1879 Grau carried out a surprise attack on the shipping in lquique. The object of his attack was the Chilean corvette ABTAO which he had been told was carrying out engine repairs. In fact ABTAO had already completed her repairs and had sailed to intercept a suspicious ship. HUASCAR, fully blacked out, entered the harbour at high speed but found the only ship in the harbour to be the MATIAS COUSINO. The subsequent noise and gunfire attracted the attention of the corvette MAGALLANES patrolling offshore under command of Cdr Latorre. He immediately entered the harbour and closing to a few metres distant attacked the HUASCAR. By so doing he diverted Grau's attention from the collier and in turn attracted the monitor COCHRANE which came to investigate what was happening. Grau once again escaped Northwards leaving the field to Lattore who overnight became a Chilean national hero.

The Chileans then improved their defence of Antofagasta and occupied other ports further North whilst Grau continued his commerce raiding. In one incident he stopped the British steamer COLOMBIA and took the opportunity of scanning the newspapers aboard. In one of them he came across a list of shipping movements in Chilean ports which enabled him to lie in wait and capture the troopship RIMAC and all the troops aboard her. This incident led to a shake-up in the Chilean naval command and Captain Galvano Riveros was promoted to Rear Admiral and replaced Williams Rebellado who was retired. Grau in HUASCAR, now fitted with torpedo tubes, decided to attack the monitor COCHRANE which his intelligence told him was immobilised with engine trouble in Caldera, north of Valparaiso. In fact she was bunkering and the surprise was on Grau. When entering Caldera he met the COCHRANE coming out. Outclassed, he beat a hasty retreat and raiding various Chilean ports on the way north arrived back in Arica on 10 August 1879.

From the RIMAC Grau had obtained knowledge of ships bringing supplies through the Straits of Magellan to Chile and to stop this he despatched the corvette UNION under command of Captain Aurelio Garcia y Garcia to destroy this shipping. Garcia sailed from Arica on 31 July and made his way as far South as Punta Are- nas by 16 August, returning unsuccessfully back to Arica on 14 September. He was unsuccessful because the Chileans had deliberately weakened their naval forces off Peru to strengthen the escorts for these ships. (Chilean ships attempted a similar interception of Peruvian shipping near Panama but were no more successful).

On 24 August Grau decided on yet another night attack on Chilean naval targets, this time at Antofagasta. His prey was the two corvettes ABTAO and MAGALLANES and two transports. He was also after the monitor BLANCO ENCALADA but once again his intelligence was faulty as she had sailed South on the 22nd August. Grau darkened ship and crept into Antofogasta harbour finding to his dismay that it was crowded with merchantmen, mostly neutral. Coming across the ABTAO he launched one of his new torpedos at her from a distance of 200 metres. The torpedo ran amok and was only deflected from hitting the HUASCAR itself by prompt action by a Lt Diaz Conseco in a ship's boat. Grau was confused by this, the dark, and the fourteen ships in the harbour and was unable to use his guns for fear of provoking an international incident if he sank a neutral. $\mathrm{He}$ retreated to Taltal and apparently vented his frustration by beating up the harbour.

On 28 August he reappeared off Antofagasta at 11 h00 to finally carry out the Peruvian plan of bombarding that city. The corvettes ABTAO and MAGALLANES and the shore guns replied. $A B T A O$, which was under repair, took several hits resulting in nine dead and twelve wounded. However a shell from the ABTAO also struck the HUASCAR and inflicted slight damage as well as wounding Lt Conseco, the torpedo deflector. Suspecting the return of the Chilean monitor BLANCO ENCALADA, Grau broke off the engagement at $17 \mathrm{~h} 15$ and giving the impression that he had once again escaped North, lay off just over the horizon from the port.

At midnight the BLANCO ENCALADA did in fact return, by which time Grau had taken his ship back to Arica. The Chilean monitor spent the next few days hunting the HUASCAR but she stayed in Arica and on 30 August 1879 was in dry dock having her bottom cleaned.

It had now become a matter of vital importance to the Chileans to catch and destroy the HUASCAR and UNION as they were rendering the Chilean lines of communication unusable. The Chilean fleet was thus brought back to Valparaiso where the ships were thoroughly overhauled. 1800 new boiler tubes were made 
by hand in Santiago and as there was no dry dock the ship's bottoms were cleaned inch by inch by divers. The ships emerged completely overhauled and with the COCHRANE's speed increased to 12 knots.

On 27 September 1879 the Chilean fleet gathered in Antofagasta where a campaign was worked out to invade Peru by land and cut off Arica and Callao whilst at the same time blockading these ports from the sea. The fleet for this purpose consisted of two squadrons of three ships each under the command of Admiral Galverino Riveros.

The first objective was to be the elimination of Grau in Arica. Grau however sailed South on 30 September and the two fleets once again passed each other at sea without meeting. Riveros thus arrived off Arica on 4 October and found it empty. He wasted no time there but turned around and headed South again with his six ships fanned out to sweep for the HUASCAR and UNION. This sweep was apparently unsuccessful and when Riveros arrived off Mejillones he sent Latorre ashore to telegraph Headquarters and find out where Grau was. Grau, now promoted Rear Admiral, was in fact South of Antofagasta raiding the small ports of Northern Chile and looking for targets of opportunity. Riveros and his aide Latorre then set a trap for Grau who turned North on 6 October and headed into it.

Based on Antofagasta, Riveros spread his net again with three ships inshore and guarding the port under Riveros, and Latorre and his three ships between 20 to 50 miles offshore. Should either sight Grau he would attempt to force him towards the other and thus close the trap.

At $03 \mathrm{~h} 30$ on 8 October the Peruvian squadron was intercepted by Riveros in what became know as the Battle of Angamos. Grau ducked away from any action, first South East and then to the East. Riveros deliberately lagged behind to allow Grau to turn North to escape. This he did and at $07 \mathrm{~h} 15$ he ran into the offshore (Northern) Chilean squadron. The Peruvians attempted to outflank the Chileans but the latter's recently overhauled ships were able to cut them off, the HUASCAR being forced South. The speedier UNION managed however to carry out the outflanking movement and getting past his opponents fought off the pursing corvette O'HIGGINS and armed transport LOA to get back to Arica.

Grau was trapped and at 09h25 the HUASCAR opened fire on the COCHRANE at 300 metres. The captain of the COCHRANE, Enrique Simpson, ignored this and closed to 220 metres before firing a broadside at the HUASCAR. All her guns hit the target and one shell caused 12 casualties and damage to the gun turret. Another knocked out the engine room telegraph and steering mechanism. The fourth destroyed the bridge, killing Admiral Grau and his flag lieutenant, Lt Ferre. The HUASCAR was thereafter unable to reply to the COCHRANE's guns which started several fires. The steering gear was hit on three separate occasions, the main

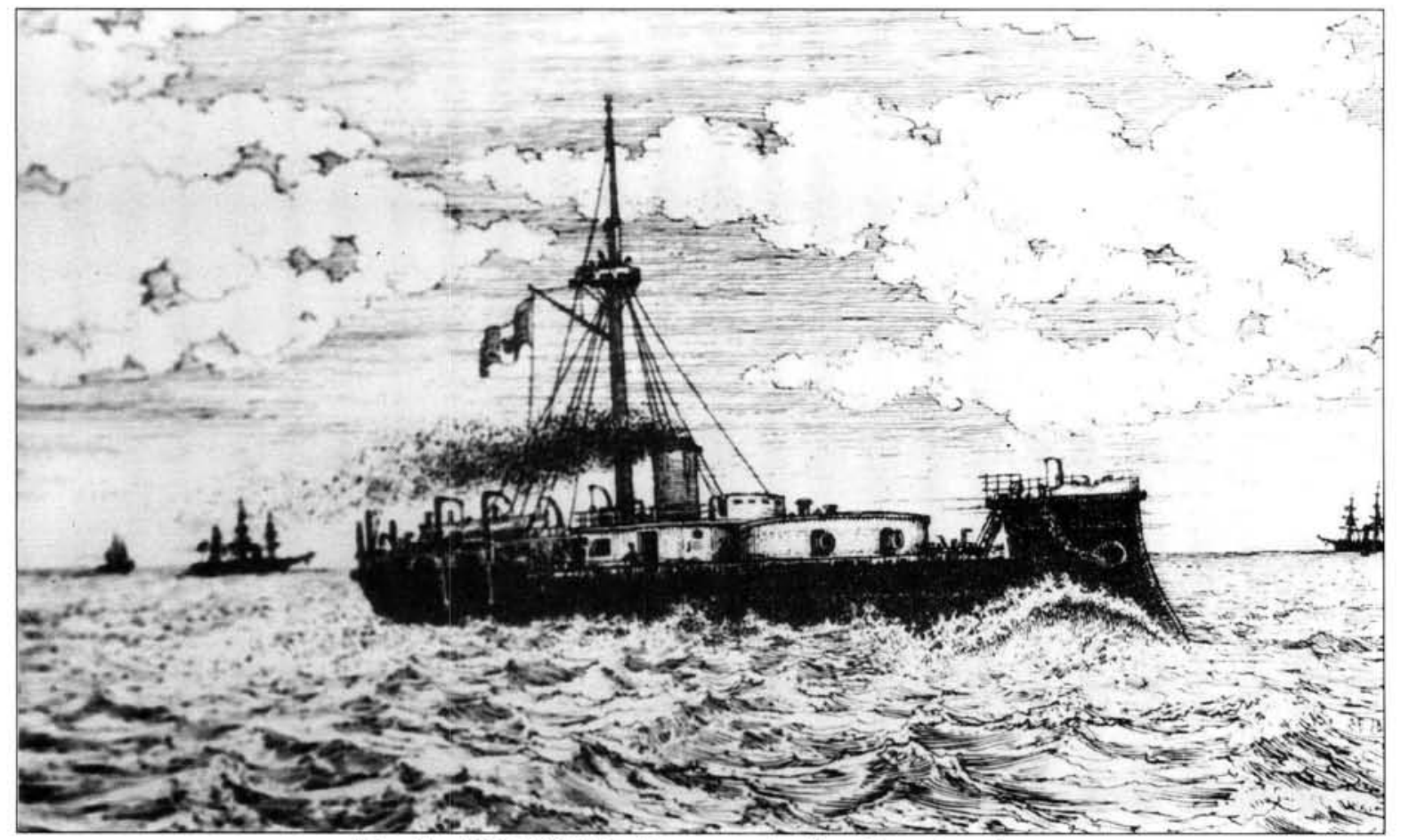

Monitor HUASCAR at sea under the Peruvian flag. 
gun turret was out of order with its gun dismounted, and her secondary armament and machine guns were put out of action. At $10 \mathrm{~h} 10$ the BLANCO ENCALADA entered the action and by $10 \mathrm{~h} 55$ the HUASCAR was dead in the water.

The Chileans then took her by boarding whilst the HUASCAR's engineers attempted to scuttle the ship but were stopped. A prize crew was put aboard, the Chilean flag was hoisted and the ship taken into Mejillones and service with the Chilean Navy in which she still is today. Her survivors went into captivity and in 1890 Grau's remains were returned to Lima in Peru for a hero's burial.

With the capture of the HUASCAR the Chileans achieved their objective of control of the sea, gaining unimpeded mobility and tying the Peruvians down to static defensive positions along their difficult and barren coastline. Mobility by land was difficult for the Peruvians and their lengthy coastline made it extremely difficult for them to fortify and defend every possible landing site.

On 2 November 1879 the Chileans put the second phase of their strategy into operation and an expedition of 10000 men in 15 transports escorted by four warships captured Pisagua. A second landing took place simultaneously at Junin, six miles to the South. The BLANCO ENCALADA captured the Peruvian corvette PILCOMAYO on 17 November and she was taken into the Chilean Navy with her name unchanged. Two days later on 19 November the Chileans won a land battle at Dolores. The Peruvian forces at lquique now found their position untenable and evacuated the area. This was an economic blow to Peru's nitrate trade as Chile now had undisputed control of the area. Following hard on the heels of the retreating Peruvians, the Chilean forces were given a severe rebuff at Tarapaca on 27 November, which then allowed the Peruvians to fall back unmolested to Arica.

Arica was the principal sea port of Southern Peru and was very heavily defended by 1858 Peruvians and nineteen guns under the command of Colonel Francisco Bolognesi. In port were a torpedo boat and the monitor MANCO CAPAC. With Chilean command of the sea Arica had come under occasional naval bombardment but on 24 February 1880 the port came under attack. 1400 Chilean troops embarked in 16 transports at Pisagua and between 26 and 28 February were landed North West of Arica at Ilo and Pacocha, to cut off Arica from help from the North. The UNION then left
Callao and successfully managed to run the seaward blockade with munitions and supplies. She arrived in Arica on 17 March and successfully returned to Callao as well. On 22 March the Chileans encircled Arica with the capture of Torata and on 26 May at the Battle of Tacana the opposing land forces met once again.

After a vicious four hour battle in which one quarter of the

22000 combatants were killed or wounded the Chileans won. Arica was taken by storm on 7 June 1880 and the MANCO CAPAC was scuttled. Chile now carried the war Northward.

On 10 April the Chilean fleet under command of Riveros blockaded Callao, Peru's chief port eight miles from Lima, the capital. It was heavily fortified with fourteen heavy guns and more than thirty 32 pounders. In port were the monitor ATAHUALPA, the UNION and a selection of minor warships, including an experimental submarine. The blockade was to last for the next nine months. The Chilean fleet rotated its ships on this duty and on 10 May the HUASCAR was engaged in an action against a school-ship, some barges and dock installations in which she received minor damage and incurred the death of her captain, Thomson.

The Peruvian Navy was reduced to cunning and booby traps and the Chilean ships JANEQUEO, LOA and COVADONGA were all victims of booby trapped launches which exploded when brought alongside. The Chileans retaliated by bombarding the ports of Chancay, Ancon, and Chorillos. In September, Capt Patricio Lynch who had seen service with the British Navy in the Opium Wars led a 3000 man amphibious force along the northern Peruvian coast between Callao and Payta to cut off the commerce of that area. The Peruvian Navy also made desperate efforts to get their experimental submarine, the TORRO SUBMARINO operational and almost succeeded. She was tested and ready for use but no appropriate target could be found.

After a futile series of peace talks in October 1880 Chilean troops began the final advance on Lima from Tacna. On 8 November a force of 22 000 men disembarked at Pisco, the guns of the fleet being used to support the Chileans ashore.

The last naval engagement took place on $6 \mathrm{De}$ cember 1880 when Chilean torpedo boats attacked a Peruvian launch. In the subsequent bombardment the Chilean torpedo boat FRESIA was sunk and the UNION damaged. On 17 December after two bloody battles at Chorillos and Miraflores the Chilean Army captured Lima, 
losing 5500 men against a Peruvian loss of 9000. When Lima fell and the news reached Callao the Peruvian Navy scuttled its remaining ships, including its submarine. Callao fell on 17 January 1881 . Organised resistance by Peru then stopped, but Bolivia fought on and this together with guerilla warfare dragged the land war out until the Treaty of Ancon on 20 October 1883 brought peace to the area.

As a result of the War of the Pacific, Chile emerged as the dominant power on the West Coast of South America and together with Argentina as one of the dominant powers of South America itself. By the end of the 19th century Chile had a massive navy and from 1800 to 1890 the Chilean Navy was superior to anything even the USA could put into the Pacific.

The Chilean Navy today has the reputation of being the best in Latin America. Whether this is in fact true or not is not a question for this article. What they do have however is a long and proud tradition of which the story of the War in the Pacific is just one example which their friends in South Africa should know about.

\section{SOURCES}

anon: Evocacion Historica do los Uniformes Navales de Chile. Armada de Chile, 1974.

Biblioteca del Oficial Historia Militar de Chile, Estado Major General del Ejercito 1969.

Espina, P.R. : Monitor Huascar. Editonel Andres Bello, Chile, 1974.

Prenafeta, Alejandro; Juan Pablo Lira Besa and Jaime Villaseca : La Armada de Chile. Editions Delriosse, Boulogne, France.

Scheina, R.L. : Latin American - A naval history. USNI Press, 1988. 